\title{
Sahul's megafauna were vulnerable to extinction due to their position in the trophic network
}

John Llewelyn ${ }^{1}$ (johnsllewelyn@gmail.com), Giovanni Strona² (goblinshrimp@gmail.com), Matthew C. McDowell ${ }^{3}$ (matthew.mcdowell@utas.edu.au), Christopher N. Johnson 4 (c.n.johnson@utas.edu.au), Katharina J. Peters ${ }^{1}$ (katharina.peters@flinders.edu.au), Daniel B. Stouffer ${ }^{5}$ (Daniel.stouffer@canterbury.ac.nz), Sara N. de Visser ${ }^{6}$ (sndevisser@hotmail.com), Frédérik Saltré1 (frederik.saltre@flinders.edu.au), Corey J. A. Bradshaw ${ }^{1}$ (Corey.Bradshaw@flinders.edu.au)

${ }^{1}$ Global Ecology, College of Science and Engineering and ARC Centre of Excellence for Australian Biodiversity and Heritage, Flinders University, GPO Box 2100, Adelaide, South Australia 5001, Australia

${ }^{2}$ Research Centre for Ecological Change, University of Helsinki, Viikinkaari 1, Biocentre 3, 00790, Helsinki, Finland

${ }^{3}$ Dynamics of Eco-Evolutionary Pattern and ARC Centre of Excellence for Australian Biodiversity and Heritage, University of Tasmania, Tasmania 7001, Australia

${ }^{4}$ School of Natural Sciences and Australian Research Council Centre of Excellence for Australian Biodiversity and Heritage, University of Tasmania, Private Bag 55, Hobart, Tasmania 7001, Australia

${ }^{5}$ Centre for Integrative Ecology, School of Biological Sciences, University of Canterbury, Christchurch, New

Zealand

${ }^{6}$ Community and Conservation Ecology, Centre for Ecological and Evolutionary Studies, University of Groningen, PO Box 11103, 9700 Groningen, The Netherlands

Short running title: Trophic cascades and megafauna

Key words: ecological network, coextinction, biotic interactions, extinction event, Late Pleistocene, food web

\section{Author contributions}

Project conceptualization by J.L., G.S., C.J.A.B., and F.S. Data curation by J.L., G.S., K.J.P., C.N.J., M.C.M., and S.N.d-V. Investigation and formal analysis by J.L., G.S., and C.J.A.B. Methodology by J.L., G.S., C.J.A.B., and D.B.S. Original draft preparation by J.L., G.S., C.J.A.B., and F.S. All authors contributed to reviewing and editing the draft.

\section{Data and code accessibility}

All relevant data and code are available at Github.com/JohnLlewelyn/Inferring-networksand-modelling-trophic-cascades (DOI: 10.5281/zenodo.3756224)

\section{Corresponding author}

John Llewelyn

Email: johnsllewelyn@gmail.com

Phone: +61 429506956

Fax: +882013399

Address: Global Ecology Lab, College of Science \& Engineering, Flinders University 


\section{Sahul's megafauna were vulnerable to extinction due to their}

\section{2 position in the trophic network}

\section{Abstract}

5 Extinctions stemming from environmental change often trigger trophic cascades and coextinctions. However, it remains unclear whether trophic cascades were a large contributor to the megafauna extinctions that swept across several continents in the Late Pleistocene. The pathways to megafauna extinctions are particularly unclear for Sahul

9 (landmass comprising Australia and New Guinea), where extinctions happened earlier than on other continents. We investigated the role of bottom-up trophic cascades in Late Pleistocene Sahul by constructing pre-extinction ( $80 \mathrm{ka}$ ) trophic network models of the vertebrate community of Naracoorte, south-eastern Australia. These models allowed us to predict vertebrate species' vulnerability to cascading extinctions based on their position in the network. We tested whether the observed extinctions could be explained by bottom-up cascades, or if they should be attributed to other external causes. Species that disappeared from the community were more vulnerable, overall, to bottom-up cascades than were species that survived. The position of extinct species in the network - having few or no predators - also suggests they might have been particularly vulnerable to a new predator. These results provide quantitative evidence that trophic cascades and naivety to predators could have contributed to the megafauna extinction event in Sahul. 


\section{Introduction}

24 Megafauna (animals $>44 \mathrm{~kg}$ ) extinctions swept across several continents during the Late

Pleistocene $(126,000-12,000$ years ago), with the highest proportions of genera lost from

Sahul (the landmass including Australia and New Guinea) and the Americas [1,2]. While the

causes of these extinctions are still debated, most evidence points toward the arrival of anatomically modern humans and/or climate change [3-5]. Irrespective of the root causes,

large extinction events always involve both primary and secondary (or co-) extinctions [6].

That is, some extinctions result from the direct impact of environmental change or over

exploitation (i.e., primary extinctions), and then coextinctions occur in species that depend

directly or indirectly on species lost to primary extinction [7-9].

Of all the extinctions that have ever occurred on Earth, many - potentially the majority have been coextinctions [10]. In some cases, these coextinctions involved host-specific parasites that were doomed by the extinction of their host species, or flowering plants imperilled by the extinction of their pollinators [11]. Coextinctions have also been mediated through trophic interactions between herbivores and vegetation, and between predators and their prey $[6,12]$. Indeed, coextinctions via trophic cascades have previously been implicated in Late Pleistocene megafauna extinctions [13,14].

Bottom-up trophic cascades, stemming from changes in the plant/primary producer community, can profoundly alter ecological communities [15]. A recent study found that the trophic group most strongly affected by changes in the plant community are herbivores [16]. Extinction risk ratings from the International Union for Conservation of Nature (IUCN) and recent extinctions suggest that herbivorous terrestrial vertebrates are indeed 
particularly vulnerable to extinction [17], a pattern that might in part be explained by the sensitivity of herbivores to bottom-up cascades. However, it remains unclear whether bottom-up cascades generally impact lower trophic levels more strongly [18], and whether bottom-up cascades and coextinctions played a role in the megafauna extinction events of the Late Pleistocene. relies heavily on understanding species interactions within an ecological community. To this end, ecological network modelling is an invaluable tool for representing ecological communities from a species-interaction perspective and studying the consequences of changes in these interactions [19]. In ecological network models, organismal groups (e.g., species, age groups, populations, or individuals) are represented by nodes, and interactions - which can be weighted or un-weighted - are represented by links. The interaction type most frequently used to build ecological network models are trophic interactions, creating networks analogous to food webs. For contemporary communities, there is a growing number of studies that use detailed information on species interactions to build network models and study trophic cascades [20-22]. Unfortunately, similar approaches are challenging to apply to palaeo communities because of the lack of data on ancient trophic interactions. However, by combining contemporary and palaeo data to infer trophic interactions, this limitation can be overcome and network models of palaeo communities can be constructed $[23,24]$. For example, Pires et al. (2015) used this approach to model Late Pleistocene mammal communities in the Americas, concluding that (1) pre-existing American mammal networks were not especially unstable (i.e., they were similar to modern networks in Africa in terms of population densities re-establishing after simulated 
perturbations), and (2) the arrival of humans destabilized the networks because this new predator increased network connectance (i.e., the proportion of potential links that are realized). However, the vulnerability of extinct versus extant species to coextinction was not tested, nor whether their conclusions would hold true in other continents presenting vastly different species assemblages.

The Late Pleistocene megafauna assemblage of Sahul was distinct from that of other continents in that all the large mammals were marsupials or monotremes [25]. Giant reptiles and birds were also a prominent component of this continent's megafauna [26]. While Sahul's megafauna included many species over the standard body-mass threshold for megafauna of $44 \mathrm{~kg}$, the term 'megafauna' is often extended in Sahul to include species with a body mass above that of their surviving relatives [25] - a definition we have adopted here. Identifying the pathways by which Sahul's unique megafauna were lost is challenging because the Late Pleistocene megafauna extinctions happened much earlier in Sahul than elsewhere [27]. To understand such ancient extinction events, a sufficient number of dated fossilized remains is necessary [28]. The most detailed and well-studied fossil record spanning the megafauna extinction event in Sahul comes from the Naracoorte region in south-eastern Australia. This fossil record offers an exceptional picture of the species living in the region over the past 500,000 years, including the ecological community at the time of the main megafauna extinction event that occurred approximately 44,000 years ago in Naracoorte [5]. Thus, the Naracoorte fossil record is the best platform available from which to model the ecological and environmental processes potentially involved in the megafauna extinction event in Sahul. 
Using Naracoorte as a model system to assess whether bottom-up coextinction cascades

were an important component of the overall extinction event in Late Pleistocene Sahul, we constructed an entire terrestrial, palaeo-vertebrate assemblage (including all terrestrial vertebrate classes), and combined this assemblage with palaeo and contemporary data to infer trophic interactions and build network models (Figure 1). These network models consisted of nodes (species) with directed, unweighted links. We then computed each species' vulnerability to coextinction via bottom-up cascades, by iteratively taking the product of the vulnerabilities of the focal species' resource nodes using an algorithm similar to PageRank. The resultant vulnerabilities were assessed in three steps: (1) we tested for a relationship between trophic level and vulnerability to coextinction, (2) we compared trophic composition of the extant (defined as species that survived the Late Pleistocene extinction event) and extinct species groups to see whether vulnerable trophic levels were over-represented in the extinct group; and (3) we focused on carnivores (the group we have the most information on regarding trophic interactions) to test whether extinct carnivores were more vulnerable to bottom-up cascades than were extant carnivores. In addition to bottom-up coextinction cascade vulnerability, we also tested for differences in the network positions of extant and extinct species to see if relative position could have made extinct species more vulnerable in other ways (e.g., more vulnerable to a new predator).

114 By incorporating interactions involving all vertebrate species, we adopted a holistic approach to studying megafauna extinctions of the Late Pleistocene. Overall, we found that extinct species were more vulnerable to coextinction than were extant species, and conclude that bottom-up trophic cascades possibly contributed to this megafauna extinction event. Our results also indicate that extinct species had fewer predators than did surviving 
bioRxiv preprint doi: https://doi.org/10.1101/2021.01.19.427338; this version posted January $20,2021$. The copyright holder for this preprint (which was not certified by peer review) is the author/funder, who has granted bioRxiv a license to display the preprint in perpetuity. It is made available under aCC-BY-NC-ND 4.0 International license.

species, suggesting extinct species might have been particularly sensitive to the arrival of the new predator (humans). By using network modelling, our study therefore demonstrates that Sahul's megafauna were vulnerable to extinction due to their relative positions in their ecological community.

\section{Methods}

125 Our aim was to develop and interrogate ecological network models representing the humans in the region ( 44,00 years ago) [5]. Below, we describe how we built ecologically realistic models of the Naracoorte network and simulated bottom-up our methods).

\section{Study region}

The World Heritage-listed (from 1994) Naracoorte Caves in south-eastern South Australia

to the surface at different locations, and at different times, over the last 500,000 years [29].

These openings acted as natural pitfall traps, capturing snapshots of Naracoorte's

137 biodiversity at different periods from at least 500,000 years ago to the present. In addition to the fossils of the many animals that fell into these natural traps, there are remains of species that lived in the caves, such as owls and bats, and their prey [30]. Consequently, the

140 Naracoorte Caves provide an ideal platform from which to build palaeo-ecological network

141 models to gain insight into how these long-lost ecosystems functioned and changed over time. 
Data

145 To build a species assemblage list (i.e., to identify the nodes to include in the network models), we used two data sources: FosSahul $2.0[28,31]$ and the Atlas of Living Australia.

147 FosSahul 2.0 is a database of dated fossil records from Sahul, including an automated 148 quality-rating method for date reliability [32]. We extracted and vetted records from the 149 Naracoorte region (defined as the region between $35^{\circ} 32^{\prime} 48^{\prime \prime} \mathrm{S}$ and $38^{\circ} 6^{\prime} 50^{\prime \prime} \mathrm{S}$, and between $139^{\circ} 10^{\prime} 42^{\prime \prime} \mathrm{E}$ and $141^{\circ} 0^{\prime} 21^{\prime \prime} \mathrm{E}$ ) from FosSahul 2.0 that had high- or intermediatequality dates ( $A^{*}, A$ or $\left.B\right)[28]$, and whose age was younger than 200,000 years before present. We chose this cut-off age to provide a large enough time period to include dated fossils from all/most megafauna species that lived in the region immediately prior to the main extinction event; if we had made the time period too narrow, few megafauna species would have been captured despite their likely presence in the region at the time. Fossil records suffer from taphonomic biases (biases in the accumulation and preservation of different organisms), and consequently some species that were present in Late Pleistocene Naracoorte are unlikely to be represented in the fossil record. Furthermore, there are biases for studying and dating particular groups of species due to academic and amateur interests

160 [33]. These biases, along with the fact that FosSahul was primarily designed to document megafauna remains rather than smaller species, means that FosSahul 2.0 does not include all vertebrate species present in Late Pleistocene Naracoorte. To account for this gap in the species list, we supplemented FosSahul 2.0 data with contemporary and historical species records from the Naracoorte Coastal Plains bioregion from the Atlas of Living Australia online repository (ala.org.au; accessed 3 January 2019). The Atlas of Living Australia has detailed species records of vertebrates from this bioregion, and so it captures most of the 
bioRxiv preprint doi: https://doi.org/10.1101/2021.01.19.427338; this version posted January 20,2021 . The copyright holder for this preprint (which was not certified by peer review) is the author/funder, who has granted bioRxiv a license to display the preprint in perpetuity. It is made available under aCC-BY-NC-ND 4.0 International license.

167

168

169

170

171

172

173

174

175

176

177

178

179

180

181

182

183

184 2700 kg (Supplementary Table S1).

diversity of extant and recently extinct vertebrate species. We extracted data pertaining to all terrestrial vertebrates from the region, and removed species that were introduced since European arrival, as well as vagrants and erroneous records (species well-outside their normal distribution and not present in the fossil record), and strictly coastal species such as marine birds that do not use inland waterways. Our final species list, built using FosSahul 2.0 and the Atlas of Living Australia, included 423 vertebrate species (Supplementary Table S1).

To infer trophic links, we required information on each species' body mass and broad trophic category (whether it ate plants and/or fungi, terrestrial invertebrates, terrestrial vertebrates, or aquatic animals). For extant species, we extracted much of this information from large databases: snake database [34]; Australian bird database [35]; PanTHERIA (mammal database) [36]; lizard database [37]; AmphiBIO (amphibian database) [38]; tropical bird database [39]; Amphibian database [40]; reptile database [41]; and Elton traits databases (mammals and birds) [42]. However, information on body mass was not available for some extant reptiles and amphibians. For these species, we estimated body mass using their body length (from field guides) and validated allometric relationships $[34,37,40,43,44]$. Extinct megafaunal species were not included in any of the aforementioned databases, so for these species we obtained data on body mass and diet from the literature (see Supplementary Table S2). The 423 vertebrate species in the Naracoorte assemblage included 109 that consumed vertebrates, 221 that consumed plants, 318 that consumed invertebrates, and 75 that consumed aquatic animals (Supplementary Table S1). Of the 423 species, 238 consumed more than one trophic group. Mean body mass ranged from $0.4 \mathrm{~g}$ to 
bioRxiv preprint doi: https://doi.org/10.1101/2021.01.19.427338; this version posted January 20,2021 . The copyright holder for this preprint (which was not certified by peer review) is the author/funder, who has granted bioRxiv a license to display the preprint in perpetuity. It is made available under aCC-BY-NC-ND 4.0 International license.

191

192

193

194

195

196

197

198

199

200

201

202

203

204

205

206

207

208

209

210

211

212

213

214

Inferring trophic links

For almost all extant species, information on trophic interactions is incomplete, but the lack of knowledge regarding trophic interactions is even greater for long-extinct species. To overcome this limitation and build realistic ecological network models, various methods have been developed for inferring trophic links using species' traits such as body size (i.e., larger predators tend to eat larger prey, and predators are usually bigger than their prey [45]). Others have built on this approach to improve prediction accuracy [46-49] by adding phylogenetic and physiological information, prohibiting impossible or unlikely links, incorporating specific morphological features such as biting force and cuticular thickness, and taking into account abundance. However, most of this research focusses on fish or invertebrates, with the effectiveness of these methods rarely applied or validated for terrestrial vertebrates (but see $[50,51]$ ).

We therefore developed and validated a new method, based on the body-size trophic niche model [45], to infer trophic links between terrestrial vertebrates. The body-size trophic niche model [45], that we adapted, consists of two quantile regressions: one defines the upper prey-size limit given predator mass, and the other defines the lower prey-size limit given predator mass. If a species falls within the upper and lower limits for a particular predator, it is inferred as potential prey for that predator. We used a large predator-prey interaction dataset to identify these body-size relationships between terrestrial predators and their prey, and tested whether these relationships varied depending on taxonomic class of the predator (i.e., did including predator class as an independent variable improve the fit of the body size quantile regressions?). 
We extracted the interaction dataset from GloBI, an online repository of biotic interactions script available at [53]).

While the inclusion of additional species traits could improve accuracy of predator-prey interaction inferences, we used only three readily available traits (broad diet, body size, and predator taxonomic class with reptiles and amphibians grouped together). We restricted our method to using these three traits because: (1) using few traits is compatible with the 
bioRxiv preprint doi: https://doi.org/10.1101/2021.01.19.427338; this version posted January $20,2021$. The copyright holder for this preprint (which was not certified by peer review) is the author/funder, who has granted bioRxiv a license to display the preprint in perpetuity. It is made available under aCC-BY-NC-ND 4.0 International license.

\section{Networks}

244 To build realistic ecological networks for the Naracoorte assemblage, we applied the trophic most assemblages (and therefore the method can be widely applied), and (3) our validation steps demonstrated the resulting trophic niche model's performance is sufficient (true skill statistic $=0.6$ when applied to the Serengeti assemblage). niche model to the species list, removed excess links between vertebrates (to account for overestimating the number of predator-prey links), and added links to non-terrestrial vertebrate food resources. However, there is uncertainty regarding which vertebrate predator/prey links to delete as well as how many links to add from non-terrestrial vertebrate food resources to vertebrates. To address this uncertainty, we used a randomization approach in the link-removal and -addition steps described below, and generated 1000 versions of the network. That is, we randomly removed (for the vertebrate predator-prey links) or added (for the herbivores, invertivores, and predators of aquatic animals) links in the range indicated as realistic based on contemporary ecological networks and species' diet breadths. Because we do not know exactly where to add or remove these links, we generated 1000 versions of the network so our results were not skewed by the particular links selected.

We used our trophic niche model to assign potential predator-prey links in the Naracoorte species assemblage. Then we assigned a probability to each potential predator-prey interaction based on the prey's position in the predator's prey-size range and a Gaussian distribution centred on this range (with a standard deviation equal to a quarter of the predator's prey-size range); the highest probability was for prey close to the centre of the 
bioRxiv preprint doi: https://doi.org/10.1101/2021.01.19.427338; this version posted January 20,2021 . The copyright holder for this preprint (which was not certified by peer review) is the author/funder, who has granted bioRxiv a license to display the preprint in perpetuity. It is made available under aCC-BY-NC-ND 4.0 International license.

prey-size range (i.e., centre of the distribution) and decreased the closer the prey was to the predator's limits. For each predator, we randomly sampled from the Serengeti overprediction density kernel (Supplementary Methods S1) to determine the proportion of links to keep, and then randomly selected from the potential links taking into account the probability of the predator-prey interaction. This procedure resulted in a vertebrate network with realistic connectance (proportion of potential links that are realized), and with most of each predator's prey closer to the centre, rather than the limits, of their prey-size range.

Terrestrial vertebrates not only consume other terrestrial vertebrates, they also consume invertebrates, plants and fungi, and aquatic animals. In addition to inferring trophic links among terrestrial vertebrates, we therefore needed to add links to vertebrates from these other food resources. However, because our study focusses on vertebrate species, and because invertebrate, plant, and fungi diversities are not well resolved for most ecosystems (including Late Pleistocene Naracoorte), we did not include detail on individual species within these groups. We therefore generated a pool of $n$ species for each group $(n=1440$ for plants, 5620 for invertebrates, and 104 for aquatic animals), with these pool numbers calculated based on the described diversity in these groups relative to terrestrial vertebrate diversity in Australia $[55,56]$. To assign links from vertebrates to species from these groups, we used published records of vertebrate diet breadth (number of species consumed) for 34 herbivores, 15 invertivores, and 6 predators of aquatic species (Supplementary Table 5). To these data, we fit kernel density estimates from which we randomly sampled (within a diet breadth range of 1 to twice the maximum diet breadth recorded for that trophic guild in 
bioRxiv preprint doi: https://doi.org/10.1101/2021.01.19.427338; this version posted January $20,2021$. The copyright holder for this preprint (which was not certified by peer review) is the author/funder, who has granted bioRxiv a license to display the preprint in perpetuity. It is made available under aCC-BY-NC-ND 4.0 International license.

Supplementary Table S5) to assign the number of links between each resource group and vertebrate consumer in each of the 1000 network models.

We completed the networks by generating links from plants to invertebrates, and from plants to aquatic animals. For these subnetworks, we randomly selected a value of connectance between 0 and 0.1 for each of the 1000 replicated models. That value defined the density of plant-invertebrate and plant-aquatic animal links (we did not generate invertebrate-invertebrate links). Each plant, invertebrate, and aquatic animal node was randomly assigned a probability from a log-Normal distribution with a mean $=0$. We then allocated links between nodes by sampling them according to these probabilities. In each simulation, we attributed the plant, invertebrate, and aquatic animal groups a $\sigma$ value defining the shape of the log-Normal distribution, randomly sampled between 0.5 and 1.5 (which varied diet overlap and competition for resources in these subnetworks). We allocated plant-invertebrate and plant-aquatic animal links until we reached the predetermined connectance. half the vertebrates in this network), we made a proportional adjustment to the number of 'in' links (food resources) depending on how many food groups they fed from. For example, if a species consumed from two groups, such as vertebrates and invertebrates, we randomly deleted half of the links from each group; if they fed from three groups, we randomly removed two-thirds of the links from each food group (and so on). We made these deletions to prevent omnivores from having inflated diet breadths. 
bioRxiv preprint doi: https://doi.org/10.1101/2021.01.19.427338; this version posted January $20,2021$. The copyright holder for this preprint (which was not certified by peer review) is the author/funder, who has granted bioRxiv a license to display the preprint in perpetuity. It is made available under aCC-BY-NC-ND 4.0 International license.

In some cases involving water birds, we used empirical evidence to avoid assigning

311 unrealistic trophic links. For example, pelicans are large and, consequently, the trophic niche model predicts that pelicans take large vertebrate prey. However, we know that pelicans are not birds of prey and do not consume large terrestrial animals. Thus, we restricted the allocation of trophic links for such birds to prevent them from feeding on unrealistically large terrestrial vertebrates (they were prevented from consuming prey that weighed over a third of their body mass).

We computed a measure of relative risk to bottom-up coextinction cascades for each node in the network based on the node's probability of losing a certain percentage $(t \%)$ of its most vulnerable resources. The resource loss threshold, $t \%$, was assigned for each of the 1000 replicated network models by randomly sampling between 0 and 1 . Since the problem of calculating a node's probability of losing a percentage of its resources is iterative (with the extinction probability of one node depending on the unknown probability of extinction of other nodes, and so on), we used an algorithmic approach similar to the popular

327 the network, and then reiterated the procedure of computing extinction risk for each node in the network as the product of the extinction risk of the $t \%$ most vulnerable nodes having outgoing links pointing towards the focal node [53]. We continued the reiteration process until the risk for all nodes stopped changing. 
We compared susceptibility of extinct versus extant species to bottom-up coextinction

cascades in two ways: (1) by assessing the vulnerability of different trophic levels and comparing their prevalence in the extinct versus extant group, and (2) by assessing the vulnerability of extinct versus extant predators (at the species level). We used a trophicrather than species-level comparison for the entire assemblage because, for most trophic groups (herbivores, invertivores, and aquatic feeders), we allocated resource-consumer links by sampling from diet-breadth density kernels without using species traits to differentiate species within the trophic group. For the trophic-level comparison, we first assessed whether vulnerability to bottom-up coextinction cascades (according to the vulnerability algorithm) differed between trophic levels, and then compared the proportion of each trophic level in the extinct versus extant groups to see whether vulnerable trophic levels were over-represented in either group. We applied a randomization test to compare the proportion of each trophic group among extinct and extant species by sampling (with replacement) 10 extant and 10 extinct species from the Naracoorte assemblage, and subtracting the number of species from the trophic level of interest in the extinct sample

348 from that number in the extant sample. We repeated this process 10,000 times and used the ensuing results to make density plots to assess whether any of the trophic groups were over-represented among extinct or extant species.

In contrast to herbivores, invertivores, and aquatic feeders, resource links differed among

353 predators depending on the species' traits. Therefore, in addition to the trophic-level comparison, we compared individual predators to see if extinct species were at a higher risk of coextinction from bottom-up cascades than were extant predators. To test this, we compared 
bioRxiv preprint doi: https://doi.org/10.1101/2021.01.19.427338; this version posted January 20,2021 . The copyright holder for this preprint (which was not certified by peer review) is the author/funder, who has granted bioRxiv a license to display the preprint in perpetuity. It is made available under aCC-BY-NC-ND 4.0 International license.

357

358

359

360

361

362

363

364

365

366

367

368

369

370

371

372

373

374

375

376

377

378

379

380

predator coextinction vulnerability data. In both models, vulnerability was the dependent

variable and species was a random effect. We compared one model (random-intercept) with no

fixed effects to another model where the species' extinction status was the only fixed effect. If

the latter model had a higher weight of evidence, it is implied that extinct and extant predators

differed in their vulnerability.

We assessed the position of extinct versus extant species in the network using 12 different

network metrics: trophic level, pageRank, betweenness centrality, eigenvector centrality,

closeness centrality (in), coreness (in), degree (in), eccentricity (in), closeness centrality (out),

coreness (out), degree (out), and eccentricity (out) (Supplementary Table S6 for metric

descriptions). Metrics followed by an 'in' or 'out' were calculated for each node using links

pointing towards (in) or away from (out) the focal node. We chose these metrics because

they are commonly used, node-level metrics describing position in the network. For each

metric, we calculated the species' mean value across the 1000 network models. After

checking for highly correlated metrics and removing those identified as redundant (i.e.,

metrics that had a Spearman's $\rho>0.8$ ), we ran a principal component analysis and visually

inspected for grouping of extinct and extant species. The reduced list of metrics included

closeness (out), eccentricity (out), degree (in and out), and PageRank.

\section{Results}

Our coextinction-vulnerability measure found that herbivores were more vulnerable to

bottom-up cascades than were species from mid- or high-trophic levels (Figure 2a).

Herbivores were over-represented among extinct species (67\% of extinct species vs. $11 \%$ of

extant species; Figure 2b), whereas the less-vulnerable species occupying mid-trophic levels 
bioRxiv preprint doi: https://doi.org/10.1101/2021.01.19.427338; this version posted January $20,2021$. The copyright holder for this preprint (which was not certified by peer review) is the author/funder, who has granted bioRxiv a license to display the preprint in perpetuity. It is made available under aCC-BY-NC-ND 4.0 International license.

381

382

383

384

385

386

387

388

389

390

391

392

393

394

395

396

397

398

399

400

401

402

403

were over-represented among extant species ( $11 \%$ of extinct species vs. $63 \%$ of extant species; Figure 2c). Carnivores made up a similar proportion of species in the extinct and extant species groups ( $22 \%$ of extinct species vs. $25 \%$ of extant species; Figure $2 d$ ).

For predatory species (the trophic group for which a species' in links differed depending on the species' traits), extinct predators were more vulnerable to bottom-up cascades than were extant predators (mean coextinction vulnerability of 0.15 and 0.09 for extinct and extant predators, respectively; Figure 3). The predator vulnerability mixed-effects model with extinction status as a fixed effect had an AICc weight (wAICc) of 0.986, meaning that this model was supported 68.9 times more than the intercept-only model (informationtheoretic evidence ratio $=0.986 / 0.014=68.9)$.

Extinct species differed from extant species in terms of their position in the network.

Principal component analysis of six network-position metrics shows that extinct and extant species fall into two distinct groups according to the first principal component (dimension 1 in Figure 4a). The main contributors to this principal component are metrics describing a node's connection to the network through its 'out' links (Figure 4a; Supplementary Figure S3). Closer examination of out links (i.e., number of predators) shows that, on average, extinct species had $<1$ predator, whereas extant species had $>8$ (Figure $4 \mathrm{~b}$ ). Indeed, the average number of predators was lower for extinct species than for extant species in all 1000 models of the Naracoorte network. Extinct species also had fewer in links (number of trophic resources), on average, than did extant species (Figure 4c). 
bioRxiv preprint doi: https://doi.org/10.1101/2021.01.19.427338; this version posted January 20,2021 . The copyright holder for this preprint (which was not certified by peer review) is the author/funder, who has granted bioRxiv a license to display the preprint in perpetuity. It is made available under aCC-BY-NC-ND 4.0 International license.

405

Our analyses demonstrate the position of extinct species in the Late Pleistocene Naracoorte network made them more vulnerable to bottom-up coextinction cascades than co-occurring extant species, suggesting that trophic cascades might have contributed to the megafauna extinction event in south-eastern Sahul. However, extinct species also had fewer predators than did extant species, a network position attribute that would likely have made them more vulnerable to the arrival of the new 'super predator' - humans [58].

Herbivores, the trophic group most vulnerable to bottom-up cascades in our analyses (as well as in field experiments involving plant and invertebrate communities) [16], were overrepresented among the extinct species from Naracoorte (Figure 2b). Furthermore, Naracoorte's extinct predators were more vulnerable to bottom-up cascades than were predatory species that survived into the Holocene (Figure 3). Together, these results suggest the species lost from Naracoorte in the Late Pleistocene tended to be those more vulnerable to bottom-up trophic cascades. This leads to the question: did vegetation change and initiate trophic cascades in Naracoorte at the same time as the megafauna disappeared? Studies in other regions of Sahul have detected shifts in vegetation roughly coinciding with or preceding megafauna extinction. Hypothesised drivers of these shifts include land-use changes associated with human arrival (i.e., fire-stick farming) $[59,60]$ and/or climate change [61]. However, there are no studies on the vegetation of Naracoorte spanning the Late Pleistocene extinction event. Nonetheless, the megafauna's disappearance from Naracoorte coincided with an unusually cool period (Supplementary Figure S3) and the arrival of humans ( 44,000 years ago) [5], offering the intriguing possibility that changes in climate or land use triggered shifts in vegetation that had consequences for higher trophic levels in the network. To evaluate this possibility, more 
bioRxiv preprint doi: https://doi.org/10.1101/2021.01.19.427338; this version posted January 20,2021 . The copyright holder for this preprint (which was not certified by peer review) is the author/funder, who has granted bioRxiv a license to display the preprint in perpetuity. It is made available under aCC-BY-NC-ND 4.0 International license.

429

studies are required to model vegetation changes in south-eastern Sahul (including the Naracoorte region), and these must be validated using the pollen record and/or other fossil data.

By considering the network position of all vertebrate species in the assemblage, a clear difference between extinct and extant species emerges: extinct species had far fewer predators than did species that survived (mean number of predators: 0.7 versus 8.1 for extinct versus extant species, respectively; Figure 4b). This predator naivety, coupled with the species' slow life histories, likely made megafauna especially vulnerable to new predators $[27,62,63]$ and suggests hunting by humans could have adversely affected megafauna. Megafauna also had fewer trophic resources, on average, than did surviving species (mean number of food species: 38.4 versus 72.7 for extinct versus extant species, respectively; Figure 4c), but this difference reflected the over-representation of herbivores (which have narrower diet breadth than other trophic groups in our models; Supplementary Table S5) among the extinct species. As palaeo-vegetation, invertebrate, trophic and climate data improve, network models can eventually incorporate this information to build more refined network models, and include more detailed top-down and bottom-up forcings to assess the plausibility of the different potential causes and pathways to extinction including what (if any) role humans played in the megafauna's demise.

In summary, our network modelling of Late Pleistocene Naracoorte suggests bottom-up coextinction cascades and/or predator naivety and the arrival of humans could have driven the megafauna extinction event in Sahul. Indeed, that our network modelling showed that extinct species were vulnerable to bottom-up cascades and new predation pressures lends 
453

454

455

456

457

458

459

460

461

462

463

464

465

466

467

468

469

470

471

472

473

474

475

476

support to recent research suggesting that climate change (that can shift vegetation and

lead to bottom-up cascades) and human arrival drove the megafauna extinction trajectories

in south-eastern Sahul [5]. Our research, along with other recent studies [23,51,65],

demonstrates that network modelling is a powerful tool for investigating and understanding ancient extinction events. By developing methods to model whole-community responses to change and validating these methods using ancient extinction events, we can also provide better estimates of the fates of contemporary communities as the sixth mass-extinction event unfolds [66].

\section{Acknowledgements}

We thank E. Reed, C. Carbone, M. Tucker, C. Dickman and V.K. Llewelyn for their constructive input.

\section{Funding}

This work was supported by the Australian Research Council Centre of Excellence for Australian Biodiversity and Heritage (grant number CE170100015).

\section{References}

1. Barnosky AD. 2004 Assessing the causes of Late Pleistocene extinctions on the continents. Science 306, 70-75. (doi:10.1126/science.1101476)

2. Koch PL, Barnosky AD. 2006 Late Quaternary extinctions: state of the debate. Annu. Rev. Ecol. Evol. Syst. 37, 215-250. (doi:10.1146/annurev.ecolsys.34.011802.132415)

3. Lorenzen ED et al. 2011 Species-specific responses of Late Quaternary megafauna to climate and humans. Nature 479, 359-364. (doi:10.1038/nature10574) 
4. Metcalf JL et al. 2016 Synergistic roles of climate warming and human occupation in Patagonian megafaunal extinctions during the Last Deglaciation. Sci. Adv. 2, e1501682. (doi:10.1126/sciadv.1501682)

5. Saltré F, Chadoeuf J, Peters KJ, McDowell MC, Friedrich T, Timmermann A, Ulm S, Bradshaw CJA. 2019 Climate-human interaction associated with southeast Australian megafauna extinction patterns. Nat. Commun. 10, 5311. (doi:10.1038/s41467-01913277-0)

6. Colwell RK, Dunn RR, Harris NC. 2012 Coextinction and persistence of dependent species in a changing world. Annu. Rev. Ecol. Evol. Syst. 43, 183-203. (doi:10.1146/annurevecolsys-110411-160304)

7. Dunne JA, Williams RJ, Martinez ND. 2002 Network structure and biodiversity loss in food webs: robustness increases with connectance. Ecol. Lett. 5, 558-567. (doi:10.1046/j.1461-0248.2002.00354.x)

8. Pimm SL. 1980 Food web design and the effect of species deletion. Oikos 35, 139. (doi:10.2307/3544422)

9. Strona G, Bradshaw CJA. 2018 Co-extinctions annihilate planetary life during extreme environmental change. Sci Rep 8, 16724. (doi:10.1038/s41598-018-35068-1)

10. Dunn RR, Harris NC, Colwell RK, Koh LP, Sodhi NS. 2009 The sixth mass coextinction: are most endangered species parasites and mutualists? Proc. $R$. Soc. B 276, 3037-3045. (doi:10.1098/rspb.2009.0413)

11. Koh LP, Dunn RR, Sodhi NS, Colwell RK, Proctor HC, Smith VS. 2004 Species coextinctions and the biodiversity crisis. Science 305, 4.

12. Estes JA et al. 2011 Trophic downgrading of Planet Earth. Science 333, 301-306. (doi:10.1126/science.1205106)

13. Galetti M et al. 2018 Ecological and evolutionary legacy of megafauna extinctions: anachronisms and megafauna interactions. Biol. Rev. 93, 845-862. (doi:10.1111/brv.12374)

14. Ripple WJ, Van Valkenburgh B. 2010 Linking top-down forces to the Pleistocene megafaunal extinctions. BioScience 60, 516-526. (doi:10.1525/bio.2010.60.7.7)

15. Aberhan M, Kiessling W. 2015 Persistent ecological shifts in marine molluscan assemblages across the end-Cretaceous mass extinction. Proc Natl Acad Sci USA 112, 7207-7212. (doi:10.1073/pnas.1422248112)

16. Scherber $C$ et al. 2010 Bottom-up effects of plant diversity on multitrophic interactions in a biodiversity experiment. Nature 468, 553-556. (doi:10.1038/nature09492) 
17. Atwood TB, Valentine SA, Hammill E, McCauley DJ, Madin EMP, Beard KH, Pearse WD. 2020 Herbivores at the highest risk of extinction among mammals, birds, and reptiles. Sci. Adv. 6, eabb8458. (doi:10.1126/sciadv.abb8458)

18. Haddad NM, Crutsinger GM, Gross K, Haarstad J, Knops JMH, Tilman D. 2009 Plant species loss decreases arthropod diversity and shifts trophic structure. Ecology Letters 12, 1029-1039. (doi:10.1111/j.1461-0248.2009.01356.x)

19. Säterberg T, Sellman S, Ebenman B. 2013 High frequency of functional extinctions in ecological networks. Nature 499, 468-470. (doi:10.1038/nature12277)

20. Boit A, Martinez ND, Williams RJ, Gaedke U. 2012 Mechanistic theory and modelling of complex food-web dynamics in Lake Constance. Ecol. Lett. 15. (doi:10.1111/j.14610248.2012.01777.x)

21. Coll M, Lotze HK, Romanuk TN. 2008 Structural degradation in Mediterranean sea food webs: testing ecological hypotheses using stochastic and mass-balance modelling. Ecosystems 11, 939-960. (doi:10.1007/s10021-008-9171-y)

22. Pocock MJO, Evans DM, Memmott J. 2012 The robustness and restoration of a network of ecological networks. Science 335, 973-977. (doi:10.1126/science.1214915)

23. Dunne JA, Labandeira CC, Williams RJ. 2014 Highly resolved early Eocene food webs show development of modern trophic structure after the end-Cretaceous extinction. Proc. R. Soc. B 281, 20133280-20133280. (doi:10.1098/rspb.2013.3280)

24. Roopnarine PD. 2006 Extinction cascades and catastrophe in ancient food webs. Paleobiology 32, 1-19. (doi:10.1666/05008.1)

25. Johnson C. 2006 Australia's mammal extinctions: a 50,000-year history. Cambridge University Press.

26. Stuart AJ. 2015 Late Quaternary megafaunal extinctions on the continents: a short review. Geol. J. 50, 338-363. (doi:10.1002/gj.2633)

27. Johnson CN et al. 2016 What caused extinction of the Pleistocene megafauna of Sahul? Proc. R. Soc. B 283, 20152399. (doi:10.1098/rspb.2015.2399)

28. Peters KJ, Saltré F, Friedrich T, Jacobs Z, Wood R, McDowell M, Ulm S, Bradshaw CJA. 2019 FosSahul 2.0, an updated database for the Late Quaternary fossil records of Sahul. Sci Data 6, 272. (doi:10.1038/s41597-019-0267-3)

29. Reed EH, Bourne SJ. 2009 Pleistocene fossil vertebrate sites of the south east region of South Australia II. T. Roy. Soc. South Aust. 133, 30-40.

(doi:10.1080/03721426.2009.10887108)

30. Macken AC, Reed EH. 2013 Late Quaternary small mammal faunas of the Naracoorte Caves World Heritage Area. T. Roy. Soc. South Aust. 137, 53-67.

(doi:10.1080/3721426.2013.10887171) 
31. Rodríguez-Rey M et al. 2016 Data descriptor: a comprehensive database of quality-rated fossil ages for Sahul's Quaternary vertebrates. Sci. Data , 7.

32. Rodríguez-Rey M et al. 2015 Criteria for assessing the quality of Middle Pleistocene to Holocene vertebrate fossil ages. Quat. Geochronol. 30, 69-79.

(doi:10.1016/j.quageo.2015.08.002)

33. Starrfelt J, Liow LH. 2016 How many dinosaur species were there? Fossil bias and true richness estimated using a Poisson sampling model. Phil. Trans. R. Soc. B 371, 20150219. (doi:10.1098/rstb.2015.0219)

34. Feldman A, Meiri S. 2013 Length-mass allometry in snakes: snake length-mass allometry. Biol. J. Linnean. Soc. 108, 161-172. (doi:10.1111/j.1095-8312.2012.02001.x)

35. Garnett ST et al. 2015 Biological, ecological, conservation and legal information for all species and subspecies of Australian bird. Sci. Data 2, 150061.

(doi:10.1038/sdata.2015.61)

36. Jones KE et al. 2009 PanTHERIA: a species-level database of life history, ecology, and geography of extant and recently extinct mammals: Ecological Archives E090-184. Ecology 90, 2648-2648. (doi:10.1890/08-1494.1)

37. Meiri S. 2010 Length-weight allometries in lizards. J. Zool. (doi:10.1111/j.14697998.2010.00696.x)

38. Oliveira BF, São-Pedro VA, Santos-Barrera G, Penone C, Costa GC. 2017 AmphiBIO, a global database for amphibian ecological traits. Sci. Data 4, 170123.

39. Read QD, Baiser B, Grady JM, Zarnetske PL, Record S, Belmaker J. 2018 Tropical bird species have less variable body sizes. Biol. Lett. 14, 20170453.

(doi:10.1098/rsbl.2017.0453)

40. Santini L, Benítez-López A, Ficetola GF, Huijbregts MAJ. 2018 Length-mass allometries in amphibians. Integr. Zool. 13, 36-45. (doi:10.1111/1749-4877.12268)

41. Slavenko A, Tallowin OJS, Itescu Y, Raia P, Meiri S. 2016 Late Quaternary reptile extinctions: size matters, insularity dominates. Global Ecol. Biogeogr. 25, 1308-1320. (doi:10.1111/geb.12491)

42. Wilman H, Belmaker J, Simpson J, de la Rosa C, Rivadeneira MM, Jetz W. 2014 EltonTraits 1.0: Species-level foraging attributes of the world's birds and mammals: Ecological Archives E095-178. Ecology 95, 2027-2027. (doi:10.1890/13-1917.1)

43. Cogger H. 2014 Reptiles and amphibians of Australia. CSIRO publishing.

44. Wilson SK, Swan G. 2008 A complete guide to reptiles of Australia. 2nd Ed. New Holland Publishers. 
45. Gravel D, Poisot T, Albouy C, Velez L, Mouillot D. 2013 Inferring food web structure from predator-prey body size relationships. Methods Ecol. Evol. 4, 1083-1090. (doi:10.1111/2041-210X.12103)

46. Brose $U$ et al. 2019 Predator traits determine food-web architecture across ecosystems. Nat. Ecol. Evol. 3, 919-927. (doi:10.1038/s41559-019-0899-x)

47. Brousseau P-M, Gravel D, Handa IT. 2018 Trait matching and phylogeny as predictors of predator-prey interactions involving ground beetles. Funct. Ecol. 32, 192-202. (doi:10.1111/1365-2435.12943)

48. Eklof A, Helmus MR, Moore M, Allesina S. 2012 Relevance of evolutionary history for food web structure. Proc. R. Soc. B 279, 1588-1596. (doi:10.1098/rspb.2011.2149)

49. McLeod AM, Leroux SJ, Chu C. 2020 Effects of species traits, motif profiles, and environment on spatial variation in multi-trophic antagonistic networks. Ecosphere 11. (doi:10.1002/ecs2.3018)

50. Morales-Castilla I, Matias MG, Gravel D, Araújo MB. 2015 Inferring biotic interactions from proxies. Trends Ecol. Evol. 30, 347-356. (doi:10.1016/j.tree.2015.03.014)

51. Pires MM, Koch PL, Fariña RA, de Aguiar MAM, dos Reis SF, Guimarães PR. 2015 Pleistocene megafaunal interaction networks became more vulnerable after human arrival. Proc. R. Soc. B 282, 20151367. (doi:10.1098/rspb.2015.1367)

52. Poelen JH, Simons JD, Mungall CJ. 2014 Global Biotic Interactions: an open infrastructure to share and analyze species-interaction datasets. Ecol. Inform.

(doi:https://doi.org/10.1016/j.ecoinf.2014.08.005 accessed on 17/04/2019)

53. Llewelyn J, Strona G, Bradshaw CJA. 2020 Inferring networks and modelling trophic cascades. GitHub and Zenodo (doi:10.5281/zenodo.3756224)

54. de Visser SN, Freymann BP, Olff H. 2011 The Serengeti food web: empirical quantification and analysis of topological changes under increasing human impact: Topological changes under human impact. J. Anim. Ecol. 80, 484-494. (doi:10.1111/j.1365-2656.2010.01787.x)

55. Chapman AD. 2009 Numbers of living species in Australia and the world.

56. Grosberg RK, Vermeij GJ, Wainwright PC. 2012 Biodiversity in water and on land. Current Biology 22, R900-R903. (doi:10.1016/j.cub.2012.09.050)

57. Page L, Brin S, Motwani R, Winograd T. 1999 The PageRank citation ranking: Bringing order to the web.

58. Darimont $\mathrm{CT}$, Fox $\mathrm{CH}$, Bryan HM, Reimchen TE. 2015 The unique ecology of human predators. Science 349, 858-860. (doi:10.1126/science.aac4249)

59. Miller GH. 2005 Ecosystem Collapse in Pleistocene Australia and a Human Role in Megafaunal Extinction. Science 309, 287-290. (doi:10.1126/science.1111288) 
60. Turney CSM et al. 2001 Redating the onset of burning at Lynch's Crater (North Queensland): implications for human settlement in Australia. J. Quaternary Sci. 16, 767771. (doi:10.1002/jqs.643)

61. DeSantis LRG, Field JH, Wroe S, Dodson JR. 2017 Dietary responses of Sahul (Pleistocene Australia-New Guinea) megafauna to climate and environmental change. Paleobiology 43, 181-195. (doi:10.1017/pab.2016.50)

62. Flannery TF. 1990 Pleistocene faunal loss: implications of the aftershock for Australia's past and future. Archaeol. Oceania 25, 45-55. (doi:10.1002/j.18344453.1990.tb00232.x)

63. Johnson CN. 2002 Determinants of loss of mammal species during the Late Quaternary 'megafauna' extinctions: life history and ecology, but not body size. Proc. R. Soc. B 269, 2221-2227. (doi:10.1098/rspb.2002.2130)

64. Wood JR, Wilmshurst JM, Rawlence NJ, Bonner KI, Worthy TH, Kinsella JM, Cooper A. 2013 A megafauna's microfauna: gastrointestinal parasites of New Zealand's extinct Moa (Aves: Dinornithiformes). PLoS One 8, e57315. (doi:10.1371/journal.pone.0057315)

65. Roopnarine PD, Angielczyk KD, Wang SC, Hertog R. 2007 Trophic network models explain instability of Early Triassic terrestrial communities. Proc. R. Soc. B 274, 20772086. (doi:10.1098/rspb.2007.0515)

66. Ceballos G, Ehrlich PR, Dirzo R. 2017 Biological annihilation via the ongoing sixth mass extinction signaled by vertebrate population losses and declines. Proc. Natl. Acad. Sci. USA 114, E6089-E6096. (doi:10.1073/pnas.1704949114) 


\section{Figure captions}

Figure 1. Example of an inferred ecological network model of the Late Pleistocene Naracoorte assemblage. Small points represent vertebrate species (nodes) and lines represent trophic interactions (links). Point colour shows trophic group (e.g., herbivores, carnivores etc), and extinct nodes are black. Due to uncertainty regarding trophic interactions, 1000 versions/models of the Naracoorte network were inferred and analysed. Plants, invertebrates and aquatic animals are shown as single large points in this figure because of the large number of nodes in these groups (see methods).

Figure 2. Vulnerability of Naracoorte trophic groups to coextinction from bottom-up coextinction cascades, and proportion of each trophic group among the extinct versus extant species groups. Panel (a) shows vulnerability to bottom-up coextinction cascades of three trophic groups: herbivores, mid-trophic level species (between trophic levels 2 and 3), and carnivores. A node's vulnerability to coextinction was determined by iteratively taking the product of the vulnerabilities of the focal node's resource nodes using an algorithm similar to PageRank. The horizontal lines inside the boxes correspond to the medians, the boxes indicate the upper and lower quartiles, whiskers show $1.5 \times$ the interquartile range, and points are outliers. Panels (b), (c), and (d) are density plots showing results from randomization tests comparing the proportion of each trophic group among the extinct versus extant species groups. A density plot centred on 0 indicates that the proportion of species belonging to that trophic group was similar/identical in the extinct and extant species groups. 
bioRxiv preprint doi: https://doi.org/10.1101/2021.01.19.427338; this version posted January $20,2021$. The copyright holder for this preprint (which was not certified by peer review) is the author/funder, who has granted bioRxiv a license to display the preprint in perpetuity. It is made available under aCC-BY-NC-ND 4.0 International license.

Figure 3. Comparison of extinct versus extant predators from the Naracoorte network in terms of their vulnerability to bottom-up coextinction cascades. A node's vulnerability to coextinction was determined by iteratively taking the product of the vulnerabilities of the focal node's resource nodes using an algorithm similar to PageRank. Plot points and error bars show mean and 95\% confidence intervals, respectively.

Figure 4. Comparison of extinct versus extant species in terms of their position in the Naracoorte trophic network. Panel a) is a biplot of the first two principal components from a principal component analysis of six variables describing species' position in the network. Panel $b$ ) is a boxplot showing the number of species that preyed on each extant versus extinct species. Panel c) is a boxplot of the number of resource nodes for extinct versus extant species. In the boxplots, the centre line indicates the median, the box shows the upper and lower quartiles, the whiskers indicate $1.5 \times$ the interquartile range, and the points are outliers. We inferred 1000 models of the Naracoorte network, and from these models calculated each species' mean value of each metric for use in the principal-components biplot, predator-diversity boxplot, and resource-diversity boxplot. 


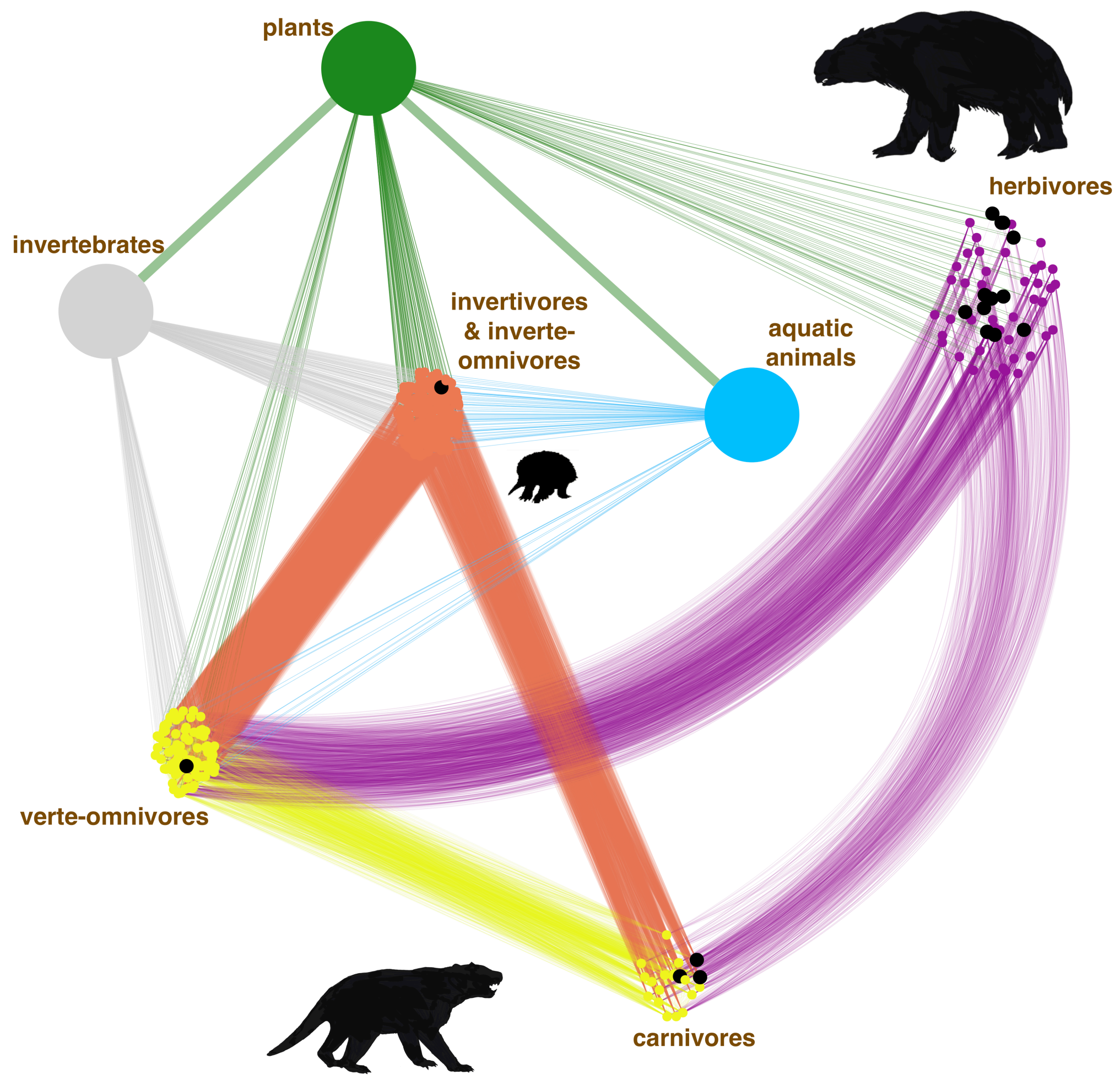

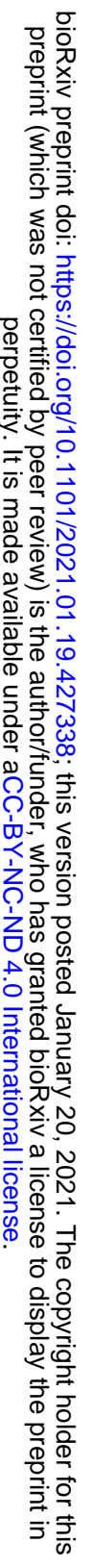


bioRxiv preprint doi: https://doi.org/10.1101/2021.01.19.427338; this version posted January 20, 2021. The copyright holder for this preprint (which was not certified by peer review) is the author/funder, who has granted bioRxiv a license to display the preprint in perpetuity. It is made available under aCC-BY-NC-ND 4.0 International license.

a)

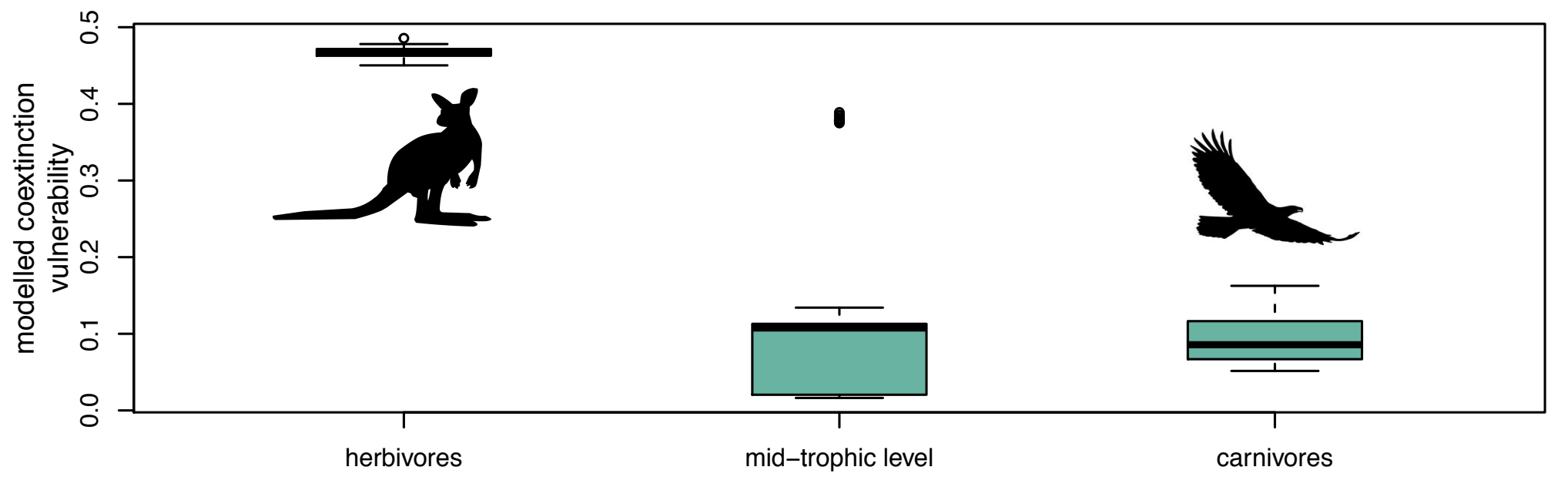

b)

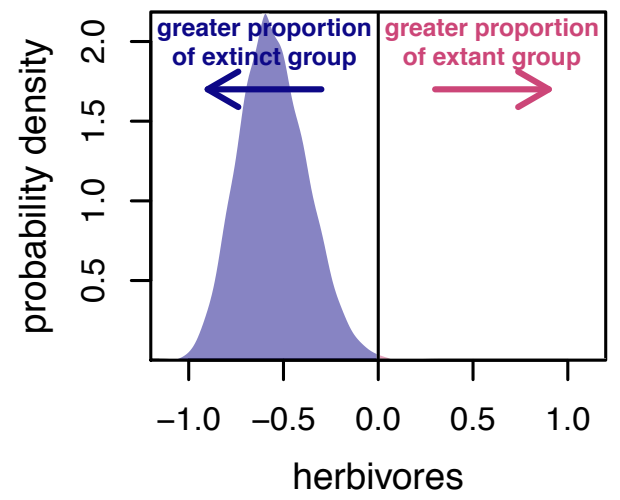

c)

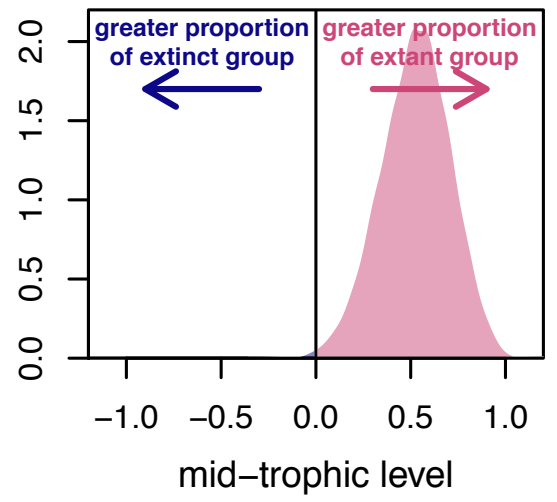

d)

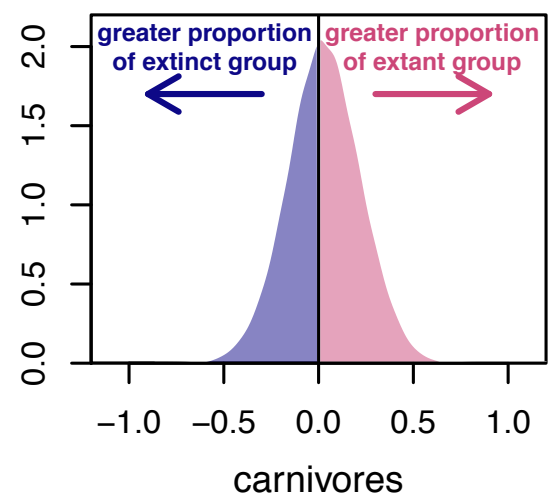

trophic group 


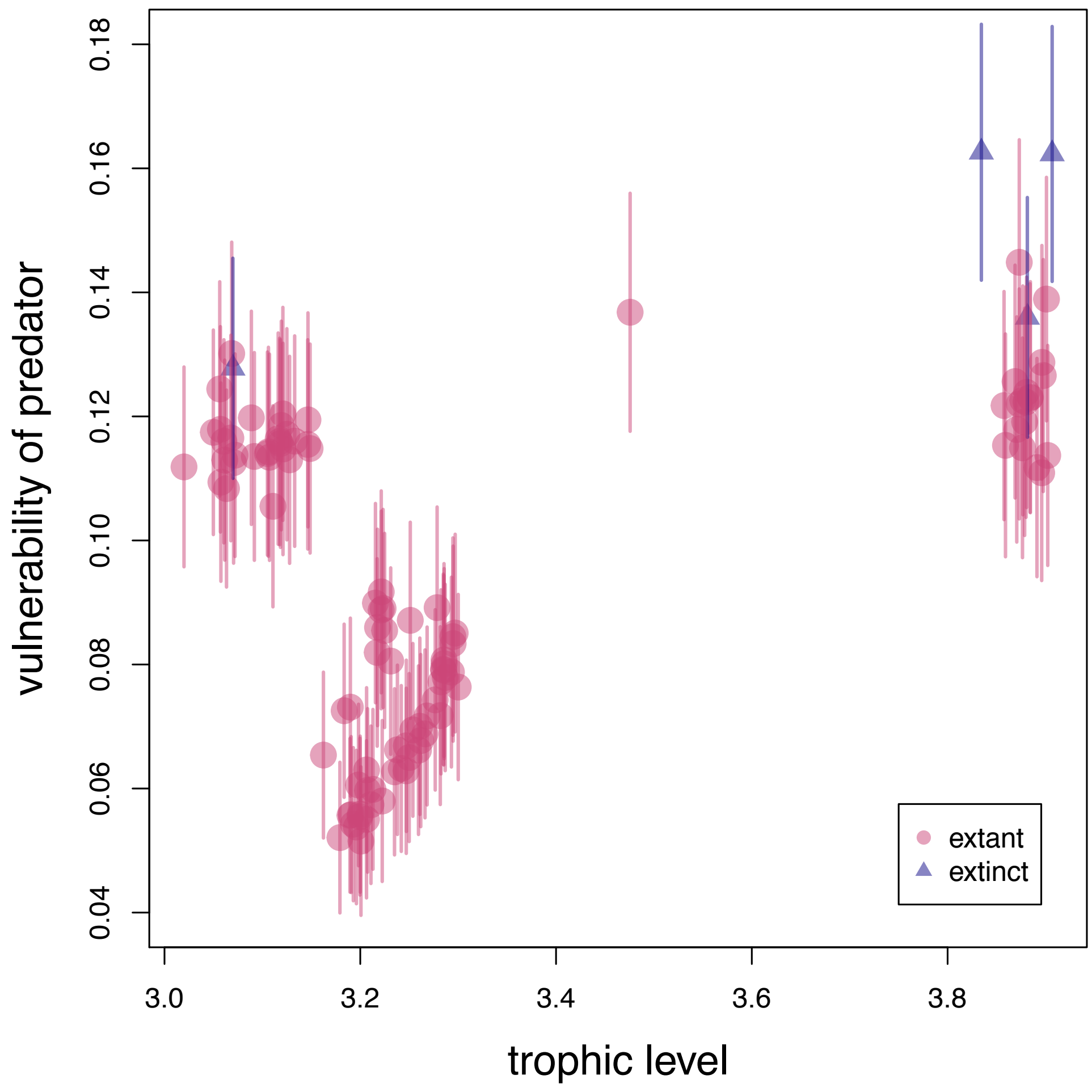


a)

eccentricity out

closeness out

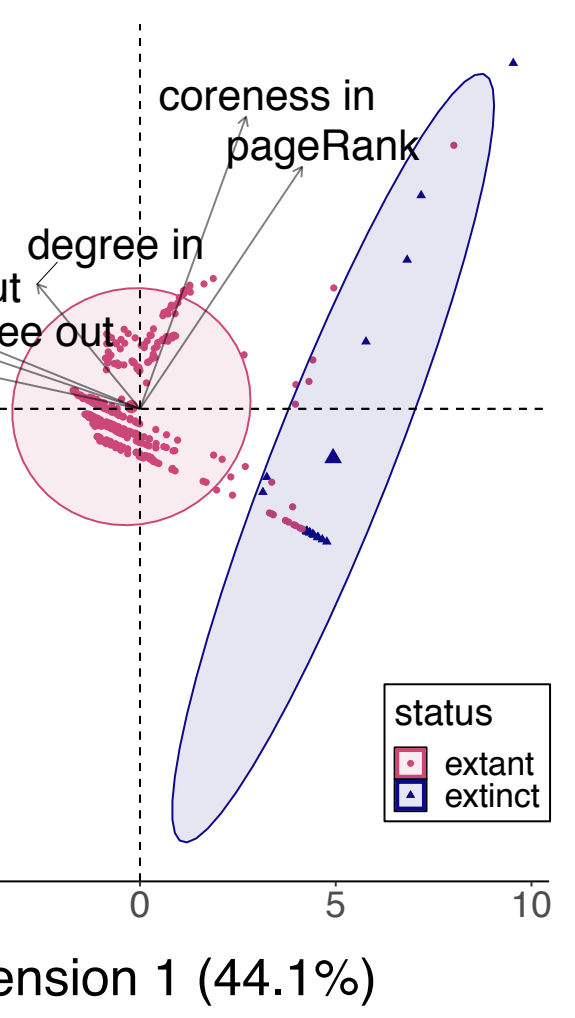

dimension 1 (44.1\%)
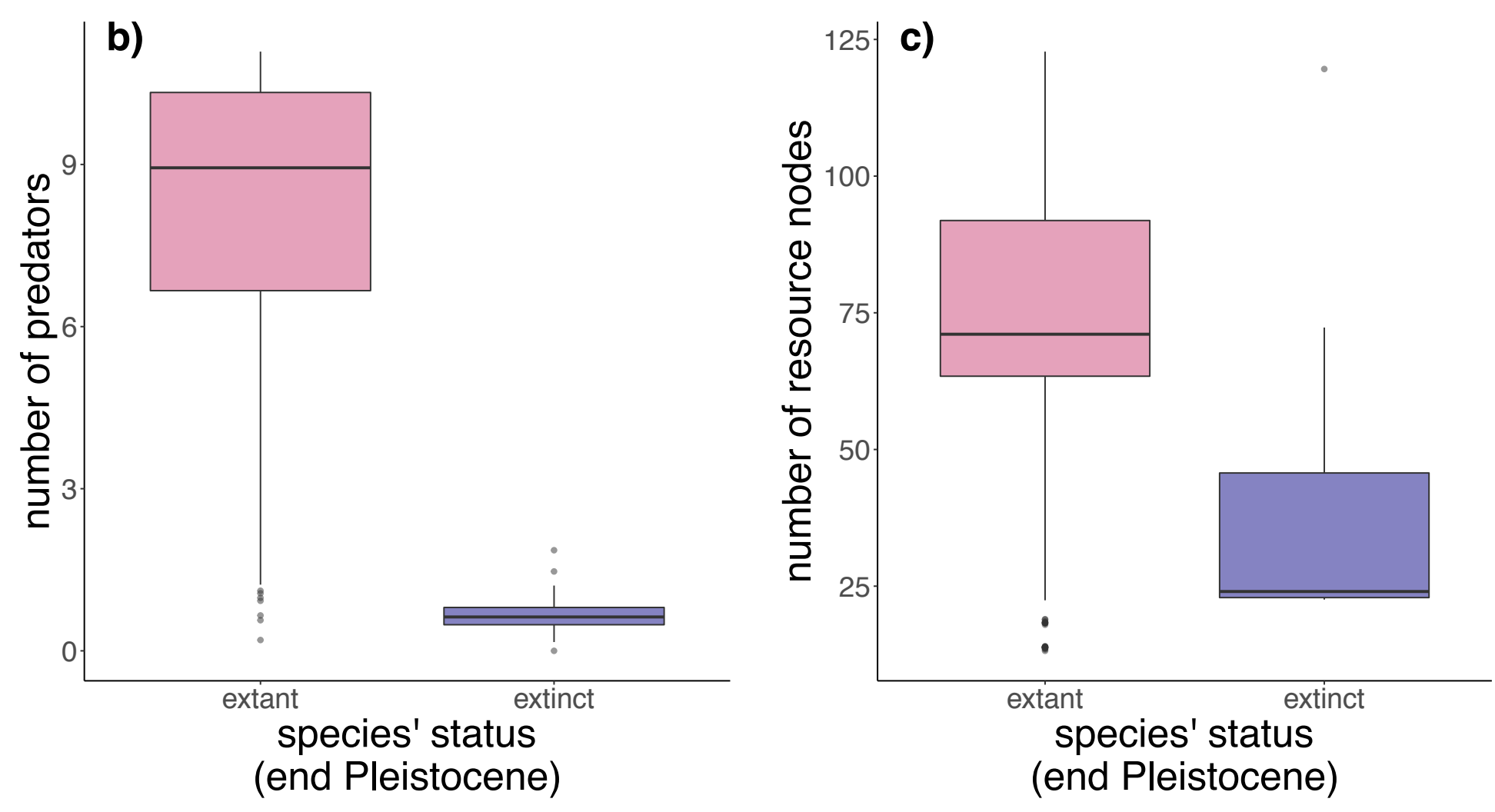